\title{
Особливості хірургічної тактики при протяжних рубцевих стриктурах стравоходу
}

\section{В. В. Бойко ${ }^{1,2}$, С. О. Савві ${ }^{1,2}$, А. Ю. Королевська ${ }^{2}$ В. В. Жидецький ${ }^{1}$ \\ ${ }^{1}$ Інститут загальної та невідкладної хірургії імені В. Т. Зайцева НАМН України, м. Харків, \\ ${ }^{2}$ Харківський національний медичний університет \\ Peculiarities of surgical tactics in long cicatricial esophageal strictures}

\author{
V. V. Boyko ${ }^{1,2}$, S. O. Savvi ${ }^{1,2}$, A. Yu. Korolebska ${ }^{2}$, V. V. Zhydetskyi ${ }^{1}$ \\ ${ }^{1}$ Zaytsev Institute of General and Urgent Surgery, Kharkiv, \\ ${ }^{2}$ Kharkiv National Medical University
}

\section{Реферат}

Мета. Поліпшення результатів лікування хворих з протяжними післяопіковими рубцевими стриктурами стравоходу (ППРСС) шляхом удосконалення існуючої хірургічної тактики.

Матеріали і методи. Представлені результати лікування 156 хворих з приводу рубцевих стриктур стравоходу за період з 2000 по 2017 рік. Хворим основної групи проводили хірургічне лікування за методикою клініки, а групі порівняння за класичними методиками оперативних втручань. Хворі І кластера підлягали одномоментній езофагопластиці, решта - двоетапному хірургічному лікуванню з накладенням контактної гастростоми (II кластер) та езофагопластикою (III кластер).

Результати. У хворих з ППРСС групи порівняння I кластера після операції ускладнення виникли у 12 (46,2\%) хворих: плеврит - у 3 (11,5\%), пневмонія - у 2 (7,7\%); померли 3 (11,5\%) пацієнта. Післяопераційні ускладнення виникли в $1(4,2 \%)$ хворого основної групи I кластера: часткова неспроможність езофагогастроанастомозу шиї. Летальність становить 4,2\% (помер 1 хворий від гострої серцево-судинної недостатності). У 4 (15,38\%) хворих II кластера групи порівняння відмічено прорізування кисетного шва, серед пацієнтів основної групи ускладнень не спостерігали. У групі порівняння III кластера ускладнення відзначали у 5 (18,5\%) хворих: у 3 (11,1\%) - часткова неспроможність езофагоколоанастомозу на шиї, у 2 (7,5\%) - некроз проксимального відділу переміщеного в позицію стравоходу товстокишкового трансплантата з повною неспроможністю езофагоколоанастомозу; померли 2 (7,5\%) пацієнта після езофагоколопластики комбінованим торакоабдомінальним доступом (гостра серцево-судинна та поліорганна недостатність). Післяопераційних ускладнень в основній групі ІІІ кластера не спостерігалося.

Висновок. Розроблена і впроваджена тактика хірургічного лікування, що базується на врахуванні трофологічного статусу та компенсаторних можливостей організму хворого з ППРСС сприяє поліпшенню результатів лікування і якості життя оперованих хворих.

Ключові слова: рубцева стриктура стравоходу; езофагопластика; гастростомія; трансхіатальний доступ.

\section{Abstract}

Objective - improvement of the treatment results in patients, suffering long post-burn cicatricial esophageal strictures (PBCES), using the existing surgical tactics.

Materials and methods. Results of treatment of 156 patients, suffering PBCES, in 2000 - 2017 yrs were presented. Surgical treatment in accordance to the Clinic method was conducted in the main group patients, and classic procedures of operative treatment were applied in the comparison group. The patients of claster I were subjected to one-staged esophagoplasty, and the rest - to two-staged surgical treatment with the contact gastrostomy performance (claster II) and esophagoplasty (claster III).

Results. Of the patients, suffering PBCES, of the comparison group claster I postoperatively in 12 (46.2\%) complications have occurred: pleuritis - in 3 (11.5\%), pneumonia - in 2 (7.7\%); 3 (11.5\%) patients died. Postoperative morbidity have occurred in $1(4.2 \%)$ patient of the main group claster I: partial insufficiency of esophagogastoanastomosis on the neck. Lethality constitutes $4.2 \%$ ( 1 patient died as a consequence of an acute cardio-vascular insufficiency). In 4 (15.38\%) patients claster II of the comparison group the pendant suture eruption was noted, among the main group patients the complications were absent. In the comparison group of claster III complications were noted in $5(18.5 \%)$ patients: in $3(11.1 \%)$ - partial insufficiency of esophagocolonoanastomosis on the neck, in $2(7.5 \%)$ - necrosis of proximal part of the large-bowel transplant, transposed into esophageal position, with total insufficiency of esophagocolonoanastomosis; and 2 (7.5\%) patients after esophagocolonoplasty, using combined thoracoabdominal access (an acute cardio-vascular insufficiency and polyorgan insufficiency), died. Postoperative complications in the main group of claster III were not observed.

Conclusion. Tactics of surgical treatment was elaborated and introduced, basing on accounting of trophologic state and compensation possibilities of organism of the patient with PBCES, promotes improvement of the treatment results and the life quality of the operated patients.

Keywords: cicatricial esophageal stricture; esophagoplasty; gastrostomy; transhiatal access.

Тактика лікування хворих з ППРСС до останнього часу залишається складною і суперечливою [1 - 3]. Це насамеред пов’язано з невеликою кількістю пацієнтів 3 цією патологією та складним, тривалим лікуванням, а також частою необхідністю виконання складних реконструктивних операцій, що не виключають інвалідизацію $[2,3]$.

Кінцевою метою лікування хворих з ППРСС є відтворення пасажу їжі природним шляхом. Сдина думка що- 


\begin{tabular}{|c|c|c|c|}
\hline \multicolumn{4}{|c|}{ Макет дослідження } \\
\hline \multicolumn{4}{|c|}{ Хірургічне лікування } \\
\hline \multicolumn{2}{|c|}{ одномоментне } & \multicolumn{2}{|c|}{ двоетапне } \\
\hline- & - & $\begin{array}{l}\text { основна група } \\
(n=26)\end{array}$ & $\begin{array}{l}\text { група порівняння } \\
(\mathrm{n}=28)\end{array}$ \\
\hline \multicolumn{2}{|c|}{$\begin{array}{c}\text { Езофагопластика } \\
\text { (I кластер) } \\
\text { (n = 50) }\end{array}$} & \multicolumn{2}{|c|}{$\begin{array}{c}\text { Езофагопластика } \\
\text { (III кластер) } \\
\text { (n=52) }\end{array}$} \\
\hline $\begin{array}{l}\text { основна група } \\
\qquad(n=24)\end{array}$ & $\begin{array}{l}\text { група порівняння } \\
(n=26)\end{array}$ & $\begin{array}{l}\text { основна група } \\
\quad(n=25)\end{array}$ & $\begin{array}{l}\text { група порівняння } \\
(n=27)\end{array}$ \\
\hline $\begin{array}{l}\text { езофагогастропластика } \\
\text { за методикою клініки }\end{array}$ & класичні методики & $\begin{array}{c}\text { езофагогастропластика } \\
\text { за методикою клініки }\end{array}$ & класичні методики \\
\hline
\end{tabular}

до вибору оптимального способу пластики стравоходу відсутня. Це стосується всіх аспектів оперативного лікування - починаючи з вибору оптимального доступу та закінчуючи вибором трансплантата для заміщення рубцево-зміненого стравоходу. Наразі існують дві основні тенденції: пластика стравоходу з використанням шлунка і товстої кишки. Застосування трансхіатального доступу для езофагопластики дозволяє проведення реконструкції пацієнтам, яким протипоказано оперативне втручання $з$ торакального доступу. При такому підході показник летальності знижується до 1\%, а у 70\% пацієнтів не виникає жодних післяопераційних ускладнень [4 - 6].

ППРСС призводять до непрохідності проксимальних відділів травного каналу з розвитком аліментарної недостатності, виснаження і згасання компенсаторних механізмів організму, тому одномоментне оперативне втручання не завжди є можливим [1 - 7].

Мета дослідження: поліпшення результатів лікування хворих з ППРСС шляхом удосконалення існуючої хірургічної тактики.

\section{Матеріли і методи дослідження}

Наведені результати лікування 156 хворих з ППРСС які знаходились у відділенні захворювань стравоходу і шлунково-кишкового тракту Інституту загальної та невідкладної хірургії імені В. Т. Зайцева з 2000 по 2017 рр.
3 метою раціоналізації дослідження та забезпечення однорідності в групах досліджуваних пацієнтів, які підлягали хірургічному лікуванню, хворих було розподілено на кластери, кожний з яких мав основну групу (хірургічне лікування за методикою клініки) та групу порівняння (класичні методики оперативних втручань) (див. таблищю)

У хворих відзначали недостатність харчування різних ступеней тяжкості, гіпотрофію I-III ступеня за В. М. Луфтом [8 - 10], вік пацієнтів від 32 до 60 років, у середньому - 37,8 року. Головними скаргами були дисфагія та втрата маси тіла.

Зважаючи на тяжкість перебігу захворювання, загального стану пацієнтів та вираженість недостатності нутритивного статусу, ми використовували наступну тактику лікування хворих (див. схему).

Усім хворим зі сформованою ППРСС при порушеннях нутритивного статусу проводили дилатацію стравоходу. При відновленні прохідності у хворого відтворюється пасаж їжі природним шляхом на певний проміжок часу $[3,9,10]$. У подальшому ці пацієнти потребують повторних курсів бужування чи балонної дилатації з подальшим виконанням реконструктивного оперативного втручання $[3,9,10]$.

За відсутності ефективності бужування та дилатації, а також неможливості їх здійснення у хворих виникає

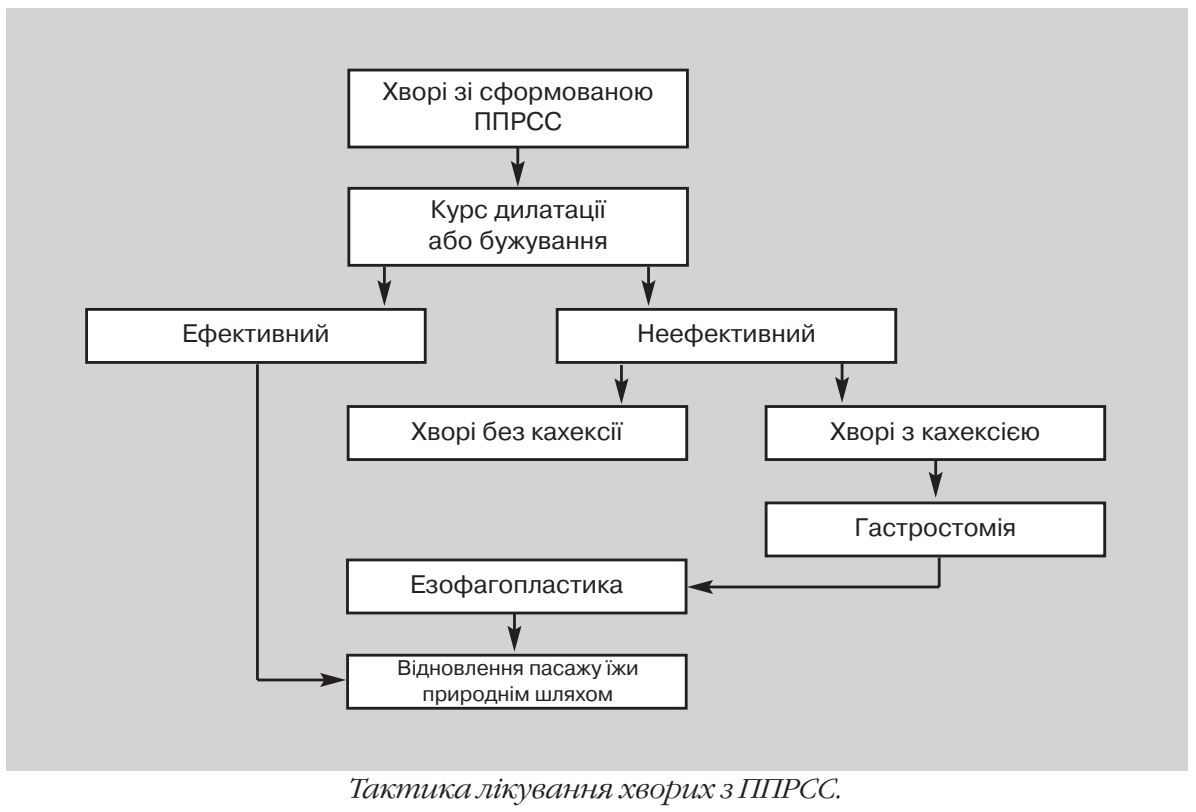


виснаження з вираженими метаболічними розладами, а іноді навіть і кахексія. Таким хворим проводили хірургічне лікування в два етапи. На І етапі формували гастростому з метою налагодження ентерального харчування та покращення трофологічного статусу. На II етапі виконували резекцію стравоходу, езофагопластику та закриття гастростомного отвору.

\section{Результати}

У хворих з ППРСС групи порівняння I кластера виконані традиційні одномоментні реконструктивновідновні оперативні втручання: езофагогастропластика - у 16 (61,5\%) хворих, езофагоколопластика - у 10 (38,5\%) хворих. Післяопераційні ускладнення виникли у 12 (46,2\%) пацієнтів. Найчастішими ускладненнями були плеврит - у 3 (11,5\%) хворих і пневмонія - у 2 (7,7\%). Після реконструктивно-відновних операцій групи порівняння померли 3 (11,5\%) хворих. Причиною смерті були медіастиніт, гостра серцево-судинна й поліорганна недостатність [11].

У зв'язку з цим розроблена і впроваджена методика одномоментної езофагогастропластики з використанням трансхіатального доступу і накладенням анастомозу на шиї (основна група) [12]

Усім хворим інтраопераційно було заведено назогастральний зонд за зону анастомозу з метою ранньої активізації та забезпечення можливості раннього післяопераційного харчування. На 6 - 7-му добу після операції проводили контрольне рентгенологічне дослідження верхніх відділів травного каналу з використанням водорозчинної контрастної речовини.

Часткова неспроможність сформованого на шиї езофагогастроанастомозу виникла в 1 (4,2\%) хворого на 7-му добу після операції. Інтраопераційно заведений в нього назогастральний зонд не видаляли, він відмежував зону неспроможності до ії закриття [6, 7]. Хворому проводили регулярні перев'язки і санації рани антисептиками. Летальність в основній групі становить 4,2\% (помер 1 хворий від гострої серцево-судинної недостатності).

В усіх пацієнтів обох груп II кластера відзначали декомпенсований ступінь непрохідності (100\%). Ослаблений стан хворих потребував в максимально короткі строки виконання гастростомії [13]. Як правило, хворі в клініку поступали в пізній післяопіковий період після формування рубцевої стриктури - 52 (96,3\%) хворих [1]. У ранній післяопіковий період 2 (3,7\%) хворим з вираженою дисфагією було накладено гастростому за Кадером. Гастростомія не потребувала розширення оперативного доступу, ії виконували з мінілапаротомії в усіх хворих обох груп II кластера.

У всіх хворих групи порівняння була сформована гастростома за Кадером. У 4 (15,4\%) пацієнтів відмічено прорізування кисетного шва 3 підтіканням шлункового вмісту і збільшення діаметра гастростомного отвору 3 мацерацією шкіри навколо нього.

У хворих основної групи прорізування швів і підтікання гастростоми не відзначали.

Усі хворі III кластера поступали в стаціонар для проведення другого етапу хірургічного лікування (езофагопластики) через $4-7$ міс. Хворим (27) групи порівняння, яким на I етапі було сформовано гастростому за
Кадером, шлунок в якості трансплантата для виконання пластики стравоходу не використовували у зв'язку з його деформацією внаслідок рубцевого процесу. Після передопераційної підготовки всім пацієнтам групи порівняння цього кластера виконано шунтуючу товстокишкову пластику стравоходу. Колотрансплантат формували з лівої половини ободової кишки зі збереженням кровопостачання за рахунок середньої або лівої ободових артерій. Ліву половину товстої кишки було використано у 15 (55,6\%), а ліву половину з додатковим підключенням сегмента сигмоподібної кишки - у 12 (54,4\%) спостереженнях. Сформований трансплантат було проведено в передньому середостінні, загрудинно [11].

У групі порівняння III кластера ускладнення виникли у 5 (18,5\%) хворих. На 6-ту та 7-му добу після операціі у $3(11,1 \%)$ хворих спостерігали часткову неспроможність езофагоколоанастомозу на шиї. При цьому у пацієнтів заведений інтраопераційно назогастральний зонд не видаляли. Він одночасно забезпечував функцію харчування та декомпресію. Цим хворим проводили регулярні перев'язки і санацію зони неспроможності антисептиками. Закриття дефекта анастомоза відбулося на 10 - 12-ту добу після іiі виникнення, що підтверджували дані рентгенологічного дослідження верхніх відділів травного каналу з використанням рентгеноконтрастної речовини, після чого трансназальний зонд видаляли. У 2 $(7,5 \%)$ пацієнтів групи порівняння III кластера в ранній післяопераційний період виник некроз проксимального відділу товстокишкового трансплантата з повною неспроможністю езофагоколоанастомозу, у зв'язку з чим виконано екстирпацію товстокишкового трансплантата. Одного (3,8\%) паціента виписали з езофагостомою та гастростомою, ще один хворий помер на 3-тю добу після операції. Післяопераційна летальність групи порівняння III кластера склала 7,5\%. Померли 2 (7,5\%) пацієнтів після езофагоколопластики комбінованим торакоабдомінальним доступом. Причиною смерті одного була гостра серцево-судинна недостатність, другий - помер після екстирпації товстокишкового трансплантата. Причиною смерті була поліорганна недостатність [12].

Віддалені результати вивчені у 21 (77,8\%) хворого в період від 6 міс. до 5 років. Стеноз анастомозу на шиї спостерігали у $3(11,1 \%)$ пацієнтів. Прохідність анастомозу у двох з них відновлено шляхом бужування. Одному (3,7\%) пацієнту не вдалося відновити прохідність езофагоколоанастомозу на тлі повної облітерації співустя. Хворому проведено реконструкцію анастомозу.

Усім хворим основної групи II кластера сформовано гастростому за методикою клініки [13].

Усім пацієнтам з ППРСС, яким на І етапі була сформована гастростома за методикою клініки, після відновлення трофологічного статусу, безуспішних спроб дилатації II етапом виконана езофагогастропластика трансхіатальним доступом. Після операції ускладнень не спостерігалося.

\section{Обговорення}

Обов'язковими умовами для виконання езофагопластики є: відсутність суттєвих порушень нутритивного статусу; задовільний стан пацієнта; лабораторні та інструментальні показники в межах норми; відсутність тяж- 
кої хронічної патології; відсутність раніше перенесених об'ємних операцій на шлунку [12, 14].

Нами розроблений спосіб одномоментної езофагогастропластики за методикою клініки, який включае лапаротомію, екстирпацію стравоходу трансхіатальним доступом і формування езофагогастроанастомозу. Попередньо проводили кліпсування лівої шлункової артерії, виконували формування майбутніх ізоперистальтичної трубки й резервуару, починаючи «поділ» від кардіального жому по малій кривизні шлунка на відстані, співвідносній діаметру стравоходу, і далі - еквідистантно його великій кривизні на тій самій відстані $[9,14]$.

У клініці розроблено двоетапний підхід до хірургічного лікування хворих з ППРСС, які мають порушення трофологічного статусу. Метою І етапу хірургічного лікування є відновлення трофологічного статусу шляхом нутритивної підтримки через сформовану контактну гастростому, відмежування зони ураження й ентеральне харчування. Після відновлення дефіциту маси тіла II етапом $є$ виконання реконструктивно-відновної операції із закриттям гастростоми і відновленням пасажу їжі природним шляхом.

Така двоетапна тактика передбачає формування гастростоми на I етапі і закриття гастростоми з виконанням пластики стравоходу з використанням підготовленого на першому етапі трансплантата із шлунка 3 формуванням анастомозу на шиї і використанням трансхіатального доступу - на II етапі.

Необхідність накладання гастростоми в ранні строки - першочергове питання для хворих з ППРСС, зважаючи на загальне виснаження організму, а іноді й кахексію. Тому оперативне втручання виконують у ранні терміни після госпіталізації, а в деяких випадках і в ургентному порядку. Для цих хворих питання обмеження об’ $€$ му та часу операції з метою зменшення ризиків інтра- та післяопераційних ускладнень є найважливішим [8 - 10].

Усім хворим основної групи II кластера сформовано гастростому за методикою клініки, яка включає формування гастростоми із стінки шлунка по його малій кривизні й виведення іiі на передню черевну стінку, а також уведення трубки для годування в сформовану гастростому. При виконанні операції проводять часткову обробку малої кривизни шлунка з кліпсуванням лівої шлункової артеріiі, формують гастростому у вигляді ізоперистальтичної трубки еквідистантно малій кривизні шлунка, при цьому довжина ізоперистальтичної трубки сумірна з відстанню до передньої черевної стінки, потім з урахуванням діаметра отвору й довжини переміщуваної гастростомної трубки обирають місце виходу на передню черевну стінку та виводять гастростому. Дистальний кінець цієї трубки прикріплюють швами до парієтальної очеревини, заднього та переднього листків піхви прямого м'яза живота та шкіри, а в сформовану гастростому вводять трубку для годування [13]. При цьому відбувається мінімальна травматизація стебла шлунка 3 мінімальним порушенням кровопостачання [13].

Езофагогастропластика за методикою клініки на II етапі лікування, який включає закриття гастростомного отвору, трансхіатальну екстирпацію стравоходу, формування анастомозу між трансплантатом і куксою стравоходу. Із гастростомної трубки формують резервуар шлунка. Резекцію стравоходу виконують додатковим шийним доступом. Трансплантатом обирають шлункову ізоперистальтичну трубку, яку сформували на попередній операції еквідистантно великій кривизні шлунка, переміщують їі трансхіатально - формують езофагогастроанастомоз на шиї [14].

У такому підході простежується системність: взаємозв'язок втручань, унаслідок чого вони можуть бути розглянуті і як самостійні втручання, і як два етапи хірургічного лікування. Необхідність виконання гастростоми виникає у разі виснаженого стану організму хворого й неможливості проведення на цьому етапі реконструктивної операції до відновлення трофологічного статусу. Характер виконання гастростоми дає змогу на наступному етапі скоротити час виконання операції [14].

Розроблена і впроваджена тактика хірургічного лікування, що базується на урахуванні трофологічного статусу та компенсаторних можливостей організму хворого з ППРСС сприяє поліпшенню результатів лікування і якості життя оперованих хворих.

\section{References}

1. Boyko VV, Yvanova YuV, Mushenko EV, Savvy SA. Method of preventing of failure of esophago-intestinal anastomoses. Shpitalna khirurgiia. 2013;3:139-40. [In Russian].

2. Boyko VV, Savvi SO, Zhydeckiiy VV, Bodrova AYu, Bikulova DU. Sposib ocinky efektyvnosti likuvannja hvoryh z gastroenterologichnymy zahvorjuvannjamy. Patent Ukrainy № 103176. 2015; Grud 23. [In Ukrainian].

3. Chernousov AF, Horobryh TV, Chernousov FA. Modern trends in the development of esophageal surgery. Herald of surgical gastroenterology. 2008;4:5-13. [In Russian].

4. Velygockiy NN. Intrathoracic stomach during plastic of the resected esophagus. Mezhdunarodniy Medycynskiy Zhurnal. 2001;1(7):61-5. [In Russian]

5. Veligockiy NN, Gorbulich AV, Teslenko IV, Trushin AS, Veligockij AN, Komarchuk VV. High esophagogastroplasty with damage of the intrathoracic parts of the esophagus. Kharkivska khirurgichna shkola. 2009;4.1(36): 41-4. [In Russian].

6. Orringer MB, Marshall B, Iannettoni MD. Eliminating the cervical esophagogastric anastomotic leak with a side-to-side stapled anastomosis. J Thorac Cardiovasc Surg. 2000 Feb;119(2):277-88. PMID:10649203. doi: 10.1016/S0022-5223(00)70183-8.

7. Parekh K, Iannettoni MD. Complications of esophageal resection and reconstruction. Semin Thorac Cardiovasc Surg. 2007;19(1):79-88. PMID: 17403462. doi: 10.1053/j.semtcvs.2006.11.002.

8. Luft VM, Luft AV. Clinical aspects of nutritional support in medicine: ideology, potentials, standards. Rosssan Open Medical Journal. 2009;(5):8-14. [In Russian].

9. Novik AA, Matveev SA, Popova TN. Assessment of life quality in medicine. Clinical Medicine. 2000;2:10-3. [In Russian].

19. Shvyreva NE, Mizikov VM, Stamov VI, Pejkarova AV. Nutritional status, anesthesia and early postoperative complications of patients after radical operations on the esophagus. Anaesthesiology and Reanimatology. 2011;3:69-73. [In Russian].

11. Farran-Teixido L, Miro-Martin M, Biondob S, Conde-Mouriñoc $\mathrm{R}$, Bettonica-Larrañagaa $\mathrm{C}$, Aranda Dansoa $\mathrm{H}$, et al. Reconstrucción esofágica en un segundo tiempo: coloplastia y gastroplastia. Cir Esp. 2008;83(5):242-6.

12. Boyko VV, Savvi SO, Zhydeckssy VV, Bodrova AYu, Novikov YA. Sposib odnomomentnoi' ezofagogastroplastyky. Patent Ukrainy № 92357. 2014 Serp 15. [In Ukrainian].

13. Boyko VV, Savvi SO, Zhydeckssy VV, Bodrova AYu, Novikov YA. Sposib kontaktnoi gastrostomii. Patent Ukrainy № 92441. 2014 Serp 15. [In Ukrainian].

14. Boyko VV, Savvi SO, Zhydeckssy VV, Bodrova AYu, Novikov YA. Sposib plastyky stravohodu shlunkom. Patent Ukrainy № 96215. 2015 Sich 2. [In Ukrainian]. 